\title{
МОРФОМЕТРИЧНА ОЦІНКА СТРУКТУРНОЇ ПЕРЕБУДОВИ ВЕНОЗНОГО РУСЛА ЯЗИКА ПРИ ДЕСКВАМАТИВНОМУ ГЛОСИТІ
}

\author{
๑М. С. Гнатюк, І. В. Боднарчук, Л. В. Татарчук \\ Тернопільський начіональний медичний університет імені І. Я. Горбачевського МОз України
}

РЕЗЮМЕ. Десквамативний глосит, як самостійна патологія, трапляється нерідко, а його діагностика доволі складна. У морфогенезі десквамативного глоситу важлива роль належить венозному руслу язика, яке при цьому захворюванні досліджене недостатньо.

Мета - кількісними морфологічними методами вивчити морфогенез венозного русла язика при десквамативному глоситі.

Матеріал і методи. Морфометрично досліджували венозне русло язика 30 білих щурів-самців, які були поділені на 2 групи. 1 група нараховувала 15 інтактних тварин, 2 - 15 щурів з десквамативним глоситом, який моделювали створенням опіків язика шляхом нанесення оцтової кислоти. Через 2 тижні від початку досліду здійснювали евтаназію експериментальних тварин кровопусканням в умовах тіопенталового наркозу. Із язика вирізали шматочки, які фіксували у 10 \% нейтральному розчині формаліну і проводили через етилові спирти зростаючої концентрації та заливали парафіном. Мікротомні зрізи завтовшки 5-7 мкм після депарафінізації фарбували гематоксиліном-еозином, за ван-Гізон, Маллорі, Вейгертом, толуїдиновим синім.

На гістологічних мікропрепаратах проводили морфометрію венозних структур язика, при якій визначали діаметр закапілярних венул, венул, венозних судин, висоту ендотеліоцитів, їх ядер, ядерно-цитоплазматичні відношення у цих клітинах, відносні об'єми пошкоджених ендотеліоцитів. Морфометричні параметри венозних судин обробляли статистично.

Результати. Встановлено, що десквамативний глосит призводив до структурної перебудови венозного русла язика. При цьому діаметр закапілярних венул збільшився на 14,2%, венул - на 16,7 \% , а вен - на 13,6 \%, порівняно з контрольними параметрами. Висота ендотеліоцитів венозних судин при десквамативному глоситі зменшилася на 4,25 \%, а діаметр їх ядер - на 4,1 \%, ядерно-цитоплазматичні відношення зросли на 5,3 \%, що свідчить про порушення структурного клітинного гомеостазу. Відносний об'єм пошкоджених ендотеліоцитів у венозному руслі збільшився у 17,4 раза.

Світлооптично в мікропрепаратах язика спостерігалися судинні розлади, що характеризувалися повнокров'ям переважно венозних судин, перивазальним набряком, стазами у венозній частині гемомікроциркуляторного русла, осередками діапедезних крововиливів. Відмічалися також дистрофічні, некробіотичні зміни епітеліоцитів, міоцитів, ендотеліоцитів, стромальних структур, інфільтративні та склеротичні процеси. Контури стінок венозних судин нечіткі, мало місце чергування набряклих склеротичних, гіпертрофованих та стоншених ділянок. Ці зміни призводили до порушення венозного відтоку, депонування крові у венах, що призводило до зростання опору її руху та до порушення дренажу венозної крові. Виявлені структурні зміни вказували на наявність вено-артеріальної реакції, спрямованої на збереження повноцінного кровопостачання досліджуваного органа. Контури вен 3 нерівномірним просвітом, варикозним розширенням, саккуляціями, звивисті, покручені. Виявлено також звужені ділянки вен з гіалізованими стінками. Наведене вище свідчить, що змодельована патологія призводить до вираженої структурної перебудови венозного русла язика, тобто до структурно-функціональних змін всіх ланок його венозної дренажної системи.

Висновок. Змодельований десквамативний глосит призводить до ремоделювання венозного русла язика, яке характеризується вираженим розширенням та повнокров'ям венозних судин, порушенням їх венозної дренажної функції, дистрофічними, некробіотичними, інфільтративними та склеротичними процесами у досліджуваному органі.

КЛючОВІ СЛОВА: десквамативний глосит; венозне русло язика.

Вступ. Десквамативний глосит - це запальнодистрофічне захворювання слизової оболонки язика, яке локалізується переважно на його спинці та бічних поверхнях. Найчастіше десквамативний глосит трапляється при захворюваннях шлунковокишкового тракту і кровотворної системи. Десквамативний глосит, як самостійна патологія, діагностується доволі часто, а його діагностика нелегка $[2,8]$. У морфогенезі десквамативного глоситу важлива роль належть венозному руслу язика, яке при цьому захворюванні досліджене недостатньо.
Мета - кількісними морфологічними методами вивчити морфогенез венозного русла язика при десквамативному глоситі.

Матеріал і методи дослідження. Кількісними морфологічними методами досліджено венозне русло язика 30 лабораторних статевозрілих білих щурів-самців, які були поділені на дві групи. До 1 групи увійшли 15 інтактних тварин, до 2-15 щурів з десквамативним глоситом, який моделювали створенням опіків язика шляхом нанесення оцтової кислоти [2]. Через 2 тижні від по- 
Огляди літератури, оригінальні дослідження, погляд на проблему, випадок з практики, короткі повідомлення чатку досліду в умовах тіопенталового наркозу здійснювали евтаназію експериментальних тварин. Із язика вирізали шматочки, які фіксували у 10 \% нейтральному розчині формаліну. Вирізані шматочки проводили через етилові спирти зростаючої концентрації та заливали парафіном. Мікротомні зрізи завтовшки 5-7 мкм після депарафінізації фарбували гематоксиліном-еозином, за ван-Гізон, Маллорі, Вейгертом, толуїдиновим синім [3].

На гістологічних мікропрепаратах проводили морфометрію венозних структур язика, при якій визначали діаметр закапілярних венул (ДЗВ), венул (ДВ), венозних судин (ДВС), висоту ендотеліоцитів (ВЕн), їх ядер (ДЯЕн), ядерно-цитоплазматичні відношення у цих клітинах (ЯЦПЕН), відносні об'єми пошкоджених ендотеліоцитів (ВОПЕн) $[1,7]$. Експериментальні дослідження та евтаназію дослідних тварин виконували із дотриманням «Загальних етичних принципів експериментів на тваринах», ухвалених Першим національним конгресом з біоетики (Київ, 2001) та відповідно до «Європейської конвенції про захист хребетних тварин, що використовуються в дослідних та інших наукових цілях» [6]. Морфометричні параметри венозних судин обробляли статистично. О6робку результатів виконано у відділі системних статистичних досліджень Тернопільського національного медичного університету імені І. Я. Горбачевського МОЗ України в програмному пакеті STATISTIKA (Stat.Soft Inc., США). Різницю між порівнюваними морфометричними параметрами визначали за критеріями Стьюдента та МаннаУітні $[1,4]$.

Результати й обговорення. Кількісні морфологічні показники венозного русла язика дослідних тварин, отримані при виконанні даної роботи, показані у таблиці 1.

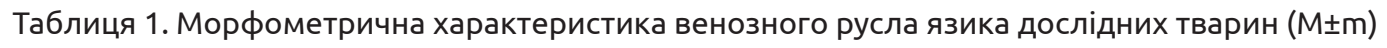

\begin{tabular}{|l|c|c|}
\hline \multirow{2}{*}{ Показник } & \multicolumn{2}{|c|}{ Група спостереження } \\
\cline { 2 - 3 } & перша & друга \\
\hline ДЗВ, мКм & $12,70 \pm 0,09$ & $14,50 \pm 0,09 * * *$ \\
\hline ДВ, мКм & $26,90 \pm 0,18$ & $31,40 \pm 0,18^{* * *}$ \\
\hline ДВС, мКм & $40,30 \pm 0,48$ & $45,80 \pm 0,51^{* * *}$ \\
\hline ВЕн, МКм & $4,70 \pm 0,04$ & $4,50 \pm 0,03^{* *}$ \\
\hline ДЯЕН, МКм & $3,50 \pm 0,03$ & $3,45 \pm 0,03^{* *}$ \\
\hline ЯЦВЕн & $0,560 \pm 0,003$ & $0,590 \pm 0,004^{* * *}$ \\
\hline ВОПЕн, \% & $2,10 \pm 0,03$ & $36,50 \pm 0,51^{* * *}$ \\
\hline
\end{tabular}

Примітка. ** - p<0,01; *** - p<0,001, порівняно з 1 групою.

При усесторонньому аналізі представлених морфометричних параметрів венозного русла язика встановлено, що при десквамативному глоситі вони суттєво змінювалися. Відомо, що венозне русло язика починається із венозної ланки гемомікроциркуляторного русла, тобто із закапілярних венул та венул. Необхідно також зазначити, що внутрішньоорганні вени досліджуваного органа за структурою суттєво відрізняються від артерій. Так, у внутрішньоорганних венах язика досить складно провести межу між внутрішнім, середнім та зовнішнім шарами судинної стінки. Структура закапілярних венул - це ендотеліоцити, розміщені на базальній мембрані. У дрібних венах ендотеліальні клітини також розміщені на базальній мембрані, але у стінці цих судин локалізуються також гладкі м'язові клітини, еластичні та колагенові волокна. Через появу гладких м'язових клітин, еластичних і колагенових волокон, вени не можуть брати участі в обмінних процесах, а виконують переважно дренаж венозної крові [7]. Гладкі міоцити у стінці вен можуть локалізуватися в один шар, трапляються осередки вен безм'язових клітин. У місцях злиття вен м'язові елементи можуть утворювати 2-3 шари.

Встановлено, що в умовах десквамативного глоситу діаметр закапілярних венул з вираженою статистичною достовірною різницею $(p<0,001)$ збільшився на 14,2 \%, а венул - на 16,7 \% (р<0,001), порівняно з контрольними параметрами. У досліджуваних умовах експерименту діаметр венозних судин зріс з $(40,30 \pm 0,48)$ мкм до $(46,70 \pm 0,54)$ мкм. Між наведеними морфометричними параметрами виявлена статистично достовірна різниця $(p<0,001)$ і останній морфологічний показник перевищував попередній на 13,6 \%.

Розширення венозних судин виявилося дещо меншим, порівняно з венозними структурами гемомікроциркуляторного русла (закапілярними венулами та венулами), що обумовлено наявністю у стінці вен м'язових структур еластичних та колагенових волокон.

Висота ендотеліоцитів венозних судин при десквамативному глоситі зменшилася на 4,25 \% ( $<<0,01)$, а діаметр їх ядер - на 4,1\% ( $<<0,01)$. Виявилися зміненими при цьому ядерно-цитоплаз- 
Огляди літератури, оригінальні дослідження, погляд на проблему, випадок з практики, короткі повідомлення матичні відношення в ендотеліоцитах. У контрольних спостереженнях вказаний морфометричний параметр дорівнював $(0,560 \pm 0,003)$, а при

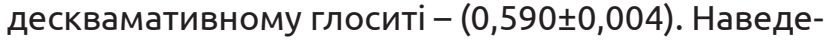
ні морфометричні параметри статистично достовірно ( $<0,001)$ відрізнялися і останній кількісний морфометричний показник перевищував попередній на 5,3 \%. Деякі дослідники вказують, що зміни ядерно-цитоплазматичних відношень у клітинах свідчать про порушення структурного клітинного гомеостазу [1]. Відносний об'єм пошкоджених ендотеліоцитів у венозному руслі при десквамативному глоситі також виявився збільшеним. При цьому вказаний морфометричний параметр з високим ступенем статистично достовірної різниці $(p<0,001)$ зріс з $(2,10 \pm 0,03) \%$ до $(36,50 \pm 0,51) \%$, тобто у 17,4 раза.

Відомо, що пошкодження значної кількості ендотеліоцитів може призводити до ендотеліальної дисфункції, блокади NO-синтази, зменшення синтезу NO, посилення синтезу ендотеліну, ангіотензину-ІІ, трибоксану, простагландину $\mathrm{H}^{2}$, що впливає на регуляцію кровотоку в досліджуваному органі та посилює ушкодження його структур $[5,7]$.

Світлооптично у мікропрепаратах язика спостерігалися судинні розлади, що характеризувалися повнокров'ям переважно венозних судин, перивазальним набряком, стазами у венозній частині гемомікроциркуляторного русла, осередками діапедезних крововиливів. Відмічалися також дистрофічні, некробіотичні зміни епітеліоцитів, міоцитів, ендотеліоцитів, стромальних структур, інфільтративні та склеротичні процеси. В

ядрах ендотеліоцитів виявлявся гіпохроматоз, пікноз та лізис. Місцями контури стінок венозних судин нечіткі, мало місце чергування набряклих склеротичних, гіпертрофованих та стоншених ділянок. Усі ці зміни призводили до порушення венозного відтоку, депонування крові у венах, що призводило до зростання опору її руху в артеріальній частині гемомікроциркуляторного русла, що підтверджувалося наявністю м'язової оболонки артеріол та артерій. Виявлені структурні зміни вказували на наявність вено-артеріальної реакції, спрямованої на збереження повноцінного кровопостачання досліджуваного органа. Контури вен з нерівномірним просвітом, варикозним розширенням, саккуляціями, звивисті, покручені. Траплялися також звужені ділянки вен з гіалізованими стінками. Наведене вище свідчить, що змодельована патологія призводить до вираженої структурної перебудови венозного русла язика, тобто до структурно-функціональних змін всіх ланок його венозної дренажної системи.

Висновок. Змодельований десквамативний глосит призводить до ремоделювання венозного русла язика, яке характеризується вираженим розширенням та повнокров'ям венозних судин, порушенням їх венозної дренажної функції, дистрофічними, некробіотичними, інфільтративними та склеротичними процесами у досліджуваному органі.

Перспективи подальших досліджень. Всебічне вивчення особливостей ремоделювання венозного русла язика при десквамативному глоситі сприятиме суттєвому покращенню діагностики, корекції та профілактики ушкоджень досліджуваного органа.

\section{ЛІТЕРАТУРА}

1. Автандилов Г. Г. Основы количественной патологической анатомии / Г. Г. Автандилов . - М. : Медицина, 2002. -240 с.

2. Герасимюк І. Є. Морфофункціональні зміни та просторова характеристика судинного русла язика при його опіках різного генезу в експерименті / І. Є. Герасимюк, О. А. Федорович // Галицький лікарський вісник. 2013. - Т. 20, № 1. - С. 26-29.

3. Горальський Л. П. Основи гістологічної техніки і морфофункціональні методи досліджень у нормі та при патології / Л. П. Горальський, В. Т. Хомич, О. І. Кононський. - Житомир : Полісся, 2011. - 288 с.

4. Лапач С. Н. Статистические методы в медико-биологических исследованиях Excell / С. Н. Лапач, А. В. Губенко, П. Н. Бабич. - К. : Морион, 2001. - 410 с.

5. Макаров М. А. Роль дисфункции эндотелия и ригидности артерий в патогенезе хронической обструктивной болезни легких / М. А. Макаров, С. Н. Авдеев, А. Т. Чучалин // Терапевтический архив. - 2012. - № 3. - С. 74-80.

6. Резніков О. Г. Загальні етичні принципи експериментів на тваринах / О. Г. Резніков // Ендокринологія. 2003. - № 1 (8). - С. 142-145.

7. Татарчук Л. В. Морфофункціональна перебудова венозного русла клубової кишки при пострезекційній портальній гіпертензії / Л. В. Татарчук // Шпитальна хірургія. - 2018. - № 4. - С. 50-53.

8. Hearnden V. Diffusion studies of nanometer polymersomes across tissue engineered human oral mucosa / V. Hearnden, H. Lomas, S. Macniel // Pharm. Res. - 2009. Vol. 26, No. 7. - P. 1718-1728. 
Огляди літератури, оригінальні дослідження, погляд на проблему, випадок з практики, короткі повідомлення REFERENCES

1. Avtadnilov, G.G. (2002). Osnovy kolichestvennoy patologicheskoy anatomii [Basis of quantitative pathological anatomy]. Moscow: Meditsina [in Russian].

2. Herasymiuk, I.Ye., \& Fedorovych, O.A. (2013). Morfofunktsionalni zminy ta prostorova kharakterystyka sudynnoho rusla yazyka pry yoho opikakh riznoho henezu v eksperymenti [Morfofunctional changes and spatial characteristics of the vascular bed of the tongue with its burns of different genesis in the experiment]. Halytskyi likarskyi visnyk - Galician Medicinal Herald, 20 (1), 26-29 [in Ukrainian].

3. Horalskyi, L.P., Khomych, V.T., \& Kononskyi, O.I. (2011). Osnovy histolohichnoi tekhniky i morfofunktsionalni metody doslidzhen u normi ta pry patolohii [Fundamentals of histological technique and morphofunctional methods of research in norm and in pathology]. Zhytomyr: Polissia [in Ukrainian]

4. Lapach, S.N., Gubenko, A.V., \& Babich, P.N. (2001). Statisticheskiye metody $v$ mediko-biologicheskikh issledovaniyakh Excell [Statistical methods in medicobiological investigations Excell]. Kyiv: Morion [in Russian].
5. Makarov, M.A., Avdieiev, S.N., \& Chuchalin, A.T. (2012). Rol disfunktsii endoteliya i regidnosti arteriy v patogeneze khronichieskoy obstruktivnoy bolezni lehkikh [The role of endothelium dysfunction and regurgitation of arteries in the pathogenesis of chronic obstructive pulmonary disease]. Terapievtichieskiy arkhiv - Therapeutic Archive, 3, 74-80 [in Russian].

6. Reznikov, O.G. (2003). Zahalni etychni pryntsypy eksperymentiv na tvarynakh [General ethical principles of experiments on animals]. Endokrynolohiia-Endocrinology, $8,1,142-145$ [in Ukrainian].

7. Tatarchuk, L.V. (2018). Morfofunktsionalna perebudova venoznoho rusla klubovoi kyshky pry postrezektsiinii portalnii hipertenzii [Morphofunctional reorganization of the venous bad of the ileum in postresection portal hypertension]. Shpytalna khirurhiia - Hospital Surgery, 4, 50-53 [in Ukrainian].

8. Hearnden, V., Lomas, H., \& Macniel, S. (2009). Diffusion studies of nanometer polymersomes across tissue engineered human oral mucosa. Pharm. Res., 26 (7), 1718-1728.

\title{
МОРФОМЕТРИЧЕСКАЯ ОЦЕНКА СТРУКТУРНОЙ ПЕРЕСТРОЙКИ ВЕНОЗНОГО РУСЛА ЯЗЫКА ПРИ ДЕСКВАМАТИВНОМ ГЛОССИТЕ
}

\author{
๑М. С. Гнатюк, И. В. Боднарчук, Л. В. Татарчук \\ Тернопольский национальный медицинский университет имени И. Я. Горбачевского МОз Украины
}

РЕЗЮМЕ. Десквамативный глоссит, как самостоятельная патология, случается нередко, а его диагностика довольно сложна. В морфогенезе десквамативного глоссита важная роль принадлежит венозному руслу языка, которое при этом заболевании исследовано недостаточно.

Цель - количественными морфологическими методами изучить морфогенез венозного русла языка при десквамативном глоссите.

Материал и методы. Морфометрически исследовано венозное русло языка 30 белых крыс-самцов, которые были поделены на две группы. Первая группа насчитывала 15 интактных животных, вторая - 15 крыс с десквамативным глосситом, который моделировали созданием ожогов языка путем нанесения уксусной кислоты. Через 2 недели от начала опыта осуществляли эвтаназию экспериментальных животных кровопусканием в условиях тиопенталового наркоза. Из языка вырезали кусочки, которые фиксировали в 10 \% нейтральном растворе формалина, проводили через этиловые спирты возрастающей концентрации и заливали парафином. Микротомные срезы толщиной 5-7 мкм после депарафинизации окрашивали гематоксилином-эозином, по ван-Гизон, Маллори, Вейгерту, толуидиновым синим. На гистологических микропрепаратах проводили морфометрию венозных структур языка, при которой определяли диаметр закапиллярных венул, венул, венозных сосудов, высоту эндотелиоцитов, их ядер, ядерно-цитоплазматические соотношения в этих клетках, относительные объемы поврежденных эндотелиоцитов. Морфометрические параметры венозных сосудов обрабатывали статистически.

Результаты. Установлено, что десквамативный глоссит приводил к структурной перестройке венозного русла языка. При этом диаметр закапилярних венул увеличился на 14,2 \%, венул - на 16,7 \%, а вен - на 13,6 \%, по сравнению с контрольными параметрами. Высота эндотелиоцитов венозных сосудов при десквамативном глоссите уменьшилась на 4,25 \%, а диаметр их ядер - на 4,1 \%, ядерно-цитоплазматические соотношения возросли на 5,3 \%, что свидетельствовало о нарушении структурного клеточного гомеостаза. Относительный объем поврежденных эндотелиоцитов в венозном русле увеличился в 17,4 раза.

Светооптически в микропрепаратах языка наблюдались сосудистые расстройства, которые характеризовались полнокровием преимущественно венозных сосудов, перивазальным отеком, стазами в венозной части гемомикроциркуляторного русла, очагами диапедезных кровоизлияний. Отмечались также дистрофические, некробиотические изменения эпителиоцитов, миоцитов, эндотелиоцитов, стромальных структур, инфильтративные и склеротические процессы. Контуры стенок венозных сосудов нечеткие, имело место чередование набухших склеротических, гипертрофированных и истонченных участков. Эти изменения приводили к нарушению венозного оттока, депонированию крови в венах, что осложнялось ростом сопротивления ее движению и нарушением дренажа венозной крови. Выявленные структурные изменения указывали на наличие вено-артериальной реак- 
Огляди літератури, оригінальні дослідження, погляд на проблему, випадок з практики, короткі повідомлення ции, направленной на сохранение полноценного кровоснабжения исследуемого органа. Контуры вен с неравномерным просветом, варикозным расширением, саккуляциями, извитые. Встречались также суженные участки вен с гиализованимы стенками. Приведенное выше свидетельствует, что смоделированная патология приводит к выраженной структурной перестройке венозного русла языка, то есть к структурно-функциональным изменениям всех звеньев его венозной дренажной системы.

Вывод. Смоделированный десквамативный глоссит приводит к ремоделированию венозного русла языка которое характеризуется расширением и полнокровием венозных сосудов, нарушением их венозной дренажной функции, дистрофическими, некробиотическими, инфильтративными и склеротическими процессами в исследуемом органе.

КЛЮЧЕВЫЕ СЛОВА: десквамативный глоссит; венозное русло языка.

\title{
MORPHOMETRIC EVALUATION OF STRUCTURAL RECONSTRUCTION OF VENOUS BED OF THE TONGUE AT DESQUAMATIVE GLOSSITIS
}

\author{
@M. S. Hnatiuk, I. V. Bodnarchuk, L. V. Tatarchuk \\ I. Horbachevsky Ternopil National Medical University
}

SUMMARY. Desquamative glossitis, as an independent pathology, is often diagnosed, and its diagnosis is not easy. In the morphogenesis of desquamative glossitis, an important role belongs to the venous vessels of the tongue, which is not sufficiently investigated for this disease.

The aim - to study the morphogenesis of the venous bed of the tongue with desquamative glossitis using quantitative morphological methods.

Material and Methods. Morphometric study of the venous bed of the tongue of 30 white male rats, which were divided into 2 groups. The group 1 consisted of 15 intact animals, $2-15$ rats with desquamative glossitis. The indicated pathology was modeled by the creation of burns of the tongue by the application of acetic acid. Euthanasia of experimental animals was carried out by bloodletting under conditions of thiopental anesthesia two weeks after the beginning of the experiment. The tongue was cut into pieces, which were fixed in a $10 \%$ neutral formalin solution after were made through ethyl alcohol of increasing concentration and filled with paraffin. Microtomy sections 5-7 $\mu \mathrm{m}$ thick after deparaffinization stained hematoxylin-eosin, van Gizon, Mallory, Weigert, toluidine blue.

On histological micropreparations, morphometry of the venous structures of the tongue was performed, in which the diameter of the capillary venules, venules, venous vessels, the height of the endothelial cells, their nuclei, nuclearcytoplasmic ratios in these cells, and the relative volumes of damaged endothelial cells were determined. Morphometric parameters of venous vessels were processed statistically.

Results and Discussion. It was established that desquamative glossitis led to the structural rearrangement of the venous bed of the tongue. The diameter of the capillary venules increased by $14.2 \%$, venules - by $16.7 \%$, and veins - by $13.6 \%$ compared to control parameters. The height of endothelial cells of venous vessels at desquamative glossitis decreased by $4.25 \%$, and the diameter of their nuclei was $4.1 \%$, and the nuclear-cytoplasmic ratio increased by $5.3 \%$, indicating a violation of structural cellular homeostasis. The relative volume of damaged endothelial cells in the venous bed increased by 17.4 times.

Optically, in the micropreparations of the tongue, vascular disorders were observed, characterized by plethora of mainly venous vessels, perivasal edema, stasis in the venous part of the hemomycocirculatory bed, and the cells of diapedeous hemorrhages. There were also dystrophic, necrosis changes in epithelial cells, myocytes, endothelial cells, stromal structures, infiltrative and sclerotic processes. The contours of the walls of the venous vessels are fuzzy, there was an alternation of swollen sclerotic, hypertrophied and groinous areas. These changes led to a violation of venous outflow, deposition of blood in the veins, which led to an increase in resistance to its movement and to disturbance of drainage of venous blood. The revealed structural changes indicated the presence of a vein-arterial reaction, aimed at maintaining a complete blood supply to the investigated organ. The contours of the veins with uneven lumen, varicose enlargement, sucking, twisting. There were also narrowed areas of veins with gated walls. The above mentioned shows that the simulated pathology leads to a pronounced structural rearrangement of the venous bed of the tongue, that is to the structural-functional changes of all parts of its venous drainage system.

Conclusion. Modified desquamative glossitis leads to the remodeling of the venous bed of the tongue, which is characterized by pronounced enlargement and pluripotency of venous vessels, a violation of their venous drainage function, dystrophic, necrosis, infiltrative and sclerotic processes in the organ examined.

KEY WORDS: desquamative glossitis; venous bed of the tongue. 